\author{
Maciej PERKOWSKI, PhD, Professor at the University of Bialystok \\ Faculty of Law, University of Bialystok \\ e-mail: maper@post.pl.
}

DOI: $10.15290 /$ ose.2016.05.83.10

\title{
IMPLICATIONS OF ARBITRATION AND MEDIATION IMPLEMENTATION FROM THE PERSPECTIVE OF BIALYSTOK
}

\begin{abstract}
Summary
In the era of progressive economic and trade cooperation at a national and international level, the number of disputes related to them is increasing. Statistics overviewing the activity of Polish courts dealing with proceedings in commercial cases confirm the fact. The development of alternative disputes resolution instruments, in particular regarding arbitration and mediation, gives rise to hope for remedying the situation. At the moment their scope is of little significance related to the entirety of legal transactions. Moreover, there are areas virtually devoid of them. The Podlaskie region is one of such areas. Recently, collaboration of the Chamber of Industry and Commerce in Bialystok and the Faculty of Law of University of Bialystok resulted in the launch of the Arbitration and Mediation Center of the Podlaskie region. As a part of the project, mediation services were commenced and further steps to launch the Eastern Court of Arbitration were taken. It seems that the undertaking can bring satisfactory results for socio-economic trading. The assumption will be possible to be verified in practice in the nearest future.
\end{abstract}

Keywords: arbitration, mediation, alternative disputes resolution instruments.

JEL: J52

\section{Introduction}

In recent years, there has been a significant progression of complex interdependencies between economics and law. On the one hand, as a rule, legislative processes take into account their economic impact, on the other hand, more often they tend to be a consequence of economically relevant processes or facts. Therefore, popularization of the concept of economic analysis of law should be emphasized. This is an interdisciplinary field that combines legal science with economic science. "Based on principles and models coming from economics, the research method of economic analysis of law puts particular emphasis on achieving maximum efficiency of regulations, which means abandoning a dogmatic analysis of law to identify factual and actual results achieved by specific legislative solutions" [Maraszek 2011, p. 8; more broadly: Bełdowski, 
Metelska-Szaniawska 2007, pp. 51-69; Tokarczyk 2007, pp. 175-184]. Several economic goals can be pointed out in law. They include:

- $\quad$ building an effective wealth deployment system;

- settlement of economic conflicts between legal entities;

- $\quad$ increase in individual and social well-being concerning tangible and intangible goods;

- $\quad$ achieving minimum economic efficiency [Stelmach, Brożek, 2007, p. 208].

The outlined phenomenon should be thus particularly considered with regard to such subjects as alternative disputes resolution (ADR), where a legal or economic perspective approach proves insufficient to present its compound character and implications.

The purpose of this paper is to disseminate the idea of ADR through presenting its specific conditions from a local perspective of Eastern Poland. The institution of ADR in Western European countries is well-established and multiple theoretical and practical studies have been published regarding the topic [see e.g. the Arbitration, dispute resolution...]. Also, Polish Law \& Economics literature on ADR gives theoretical fundaments for a scientific account of the subject. The paper's aim is, however, to give an image of mediation and arbitration in the spirit of the Law in Action concept - showing a practical impact of applying a certain legal solution on the region's economy in the most important moment of taking action.

\section{Excessive length of judicial proceedings in the Polish courts of general jurisdiction}

Entrepreneurs embody the economic and legal interdependencies. Of course, a voice from a single trader does not translate directly into a legal effect. As such voices are heard in a large number - "drops of water wear away a stone". The dependence is very clearly reflected in the issue of the excessive length of judicial proceedings. It is a situation when the time from the beginning to the end of judicial proceedings extends to an extent in which ensuring the immediacy of justice is impossible. In other words, it comes too late to provide the sense of justice, public or private interest, as well as the image of courts and social trust towards them. Naturally, when there are objective or subjective reasons (e.g. particular complexity of facts, complexity of legal issues, force majeure, etc.), a reasonable extension of court proceedings is possible. However, while the same excessive length of judicial proceedings is a bad thing, its progression becomes alarming. The progression in the average duration of court proceedings in commercial cases is of a particular concern, as shown in the following chart (see Chart 1.). 
CHART 1.

The average duration of court proceedings in commercial law cases in first instance in regional and district courts in 2010-2014 (in months)

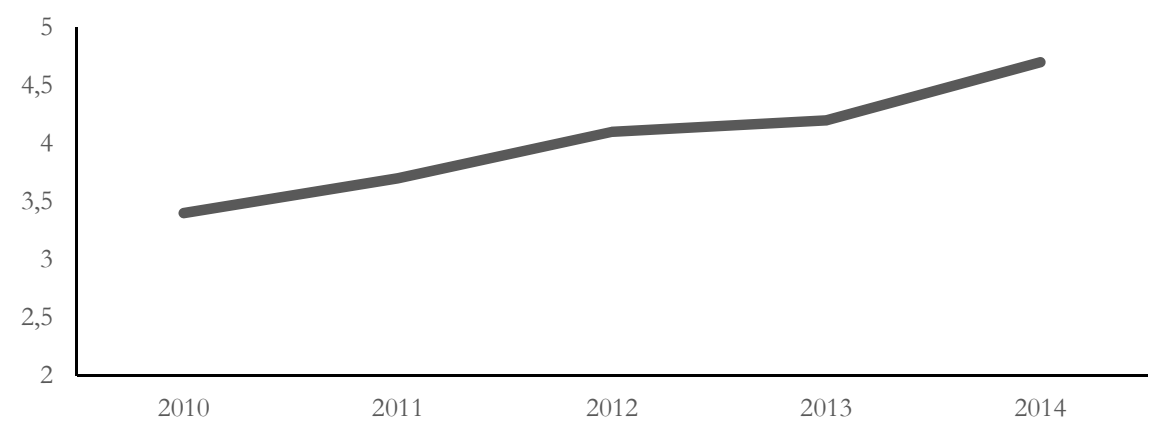

Source: own study based on: [Complaint against excessive length of proceedings..., 2015, s. 9].

The average duration of proceedings in commercial law cases in the period increased by almost $40 \%$ (i.e. by more than a month in relation to the average value for 2010 of approx. 3.5 months).

High hopes for remedying the situation have been pinned on the European Court of Human Rights in Strasbourg, which, referring to complaints by individuals dissatisfied with decisions of national courts (payable under the European Convention on Human Rights and Fundamental Freedoms after the exhaustion of the national course of proceedings), strongly denounced the excessive length of judicial proceedings [http://bip.ms.gov.pl/pl/prawa-czlowieka/europejski-trybunal-praw-czlowieka/ podstawowe-informacje-dotyczace-skladania-skargi-do-europejskiego-trybunalu-prawczlowieka/ (accessed: of 18.04.2015); Keller, Forowicz, Engi, 2010].

Unfortunately, international courts (including the Strasbourg Court) began to fall in chronicity, which became the highlight of recent complaints about the excessive length of the EU criminal justice system [http://www.lex.pl/czytaj/-/artykul/ets-bedziemogl-byc-pozwany-za-przewlekly-proces, as of 18.04.2015]. Moreover, the Strasbourg Court was engaged generally in criminal law cases (which in the social perception are associated with the essence of human rights), and subsequently Polish cases related to civil, administrative, etc. law have started to occur. Although the Court has repeatedly stated delays of Polish courts and the state had to bear consequences, there has been no sanitation.

As reasons for the excessive length of judicial proceedings, a prolonged waiting period for experts' opinions and the lack of an adequate system controlling their qualifications are frequently mentioned [Information on the activities of the Ombudsman in 2013 and on observance of human and civil rights and freedoms, 2014, p. 49]. Parties rebel against the pathological excessive length of judicial proceedings. On the one hand, it manifests in disapproval of the public and numerous "watchdog" projects 
(mobilizing the judiciary to act), on the other hand, an increase in the number of formal complaints about excessive length of proceedings is noticeable (see Table 1.).

TABLE 1.

The number of complaints about excessive length of proceedings taking into account the mode of case settlement and the amount of awarded damages

\begin{tabular}{|c|c|c|c|c|c|c|c|}
\hline \multirow{3}{*}{ Year } & \multirow[t]{3}{*}{ Submitted } & \multicolumn{5}{|c|}{ Settled } & \multirow{3}{*}{$\begin{array}{l}\text { Total amount of } \\
\text { compensation } \\
\text { awarded } \\
\text { (PLN) }\end{array}$} \\
\hline & & \multirow[b]{2}{*}{ 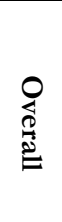 } & \multicolumn{4}{|c|}{ including } & \\
\hline & & & 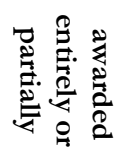 & 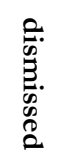 & 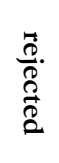 & 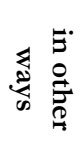 & \\
\hline 2010 & 158 & 149 & 44 & 68 & 26 & 11 & 93500 \\
\hline 2011 & 259 & 255 & 69 & 95 & 60 & 31 & 177600 \\
\hline 2012 & 327 & 314 & 113 & 108 & 77 & 16 & 253517 \\
\hline 2013 & 558 & 516 & 125 & 204 & 125 & 62 & 295874 \\
\hline 2014 & 732 & 732 & 177 & 255 & 227 & 73 & 414300 \\
\hline
\end{tabular}

Source: own study based on: [Complaint against excessive length of proceedings..., 2015, p. 10].

In comparison to the data from 2010 the number of complaints on the excessive length of proceedings in commercial cases has increased almost fivefold. The total amount of adjudicated compensations is also growing with the same rate. Entrepreneurs base their businesses on the motto: "Time is money" and the excessive length of judicial proceedings makes the core of their claims outdated, completely destroying it, and even leading businesses to bankruptcy.

The accession of Poland to the European Union, the intensive implementation process of EU aid, as well as the natural socio-economic development (in three decades from the political transformation) resulted in an increase in the number of contentious commercial cases brought before courts (see Table 2.).

TABLE 2.

The number of proceedings in commercial cases to be heard by courts in 2010-2014

\begin{tabular}{|c|c|c|c|c|c|c|}
\hline \multicolumn{2}{|c|}{ Description } & $\mathbf{2 0 1 0}$ & $\mathbf{2 0 1 1}$ & $\mathbf{2 0 1 2}$ & $\mathbf{2 0 1 3}$ & $\mathbf{2 0 1 4}$ \\
\hline \multicolumn{2}{|c|}{ District courts } & 26669 & 34008 & 46598 & 60938 & 72047 \\
\hline \multirow{2}{*}{$\begin{array}{c}\text { Regional } \\
\text { courts }\end{array}$} & first instance & 6707 & 7535 & 10309 & 13348 & 15454 \\
\cline { 2 - 7 } & appeals & 1084 & 1545 & 2603 & 2656 & 3084 \\
\hline \multicolumn{2}{|c|}{ Appellate courts } & 660 & 719 & 948 & 1320 & 1700 \\
\hline \multicolumn{2}{|c|}{ Total } & $\mathbf{3 5 1 2 0}$ & $\mathbf{4 3 \mathbf { 8 0 7 }}$ & $\mathbf{6 0 4 5 8}$ & $\mathbf{7 8 2 6 2}$ & $\mathbf{9 2} \mathbf{2 8 5}$ \\
\hline
\end{tabular}

Source: own study based on: [Quantitative analysis..., 2015, p. 2]. 
The Ministry of Justice of Poland and the Presidents of Polish courts were faced with the necessity to bring a remedy the complex situation. Changes cannot always be introduced comprehensively, quickly and effectively. If it cannot be done directly, is it not possible to create an alternative or parallel solution? It seems that such a solution is provided by alternative dispute resolutions [Blake, Browne, Sime, 2014; Partidge, 2009; Paulsson, 2013; Rogers, 2014; Steffek, 2013].

\section{Mediation and arbitration as key alternative dispute resolutions}

Settling disputes in ways alternative to the court path has its origins in the ancient times. Relevant persons or institutions were engaged in a conflict resolution in a simpler, faster and cheaper way than it was a case at courts. The means of dispute settlement known then were mediation and arbitration. These forms generally have existed till today.

Contemporary arbitration operates on the basis of international agreements, European Union law, national legislation (codes, trade agreements, rules of arbitration courts, informal codes of ethics and customs). Arbitration court system in Poland is based mainly on the Code of Civil Procedure [Law of 17 November 1964. Part V]. In the light of its provisions, arbitration is conducted usually by a non-state entity that adjudicates on civil law disputes submitted to be resolved on the basis of the arbitration clause [Report: Amicable settlement..., 2014, p. 15]. The arbitration clause is an agreement between parties of a dispute (in the case of permanent consumer arbitration courts operating at the Trade Inspection Office - a contract between a consumer and an entrepreneur), whose purpose is to consent to submit a dispute arising between them to arbitration. In the content of such agreements an object of disputes or a legal relationship from which a dispute arose are primarily indicated [Report: Amicable settlement..., 2014, p. 15]. Commercial arbitration is of the greatest importance with regard to socio-economic trading.

Mediation (mediare, Latin - "to stay in the centre"), is based on voluntary and confidential meetings or activities of parties in conflict in the presence of a mediator (a neutral person, not involved in the dispute, "non-judge"), whose aim is to elaborate an agreement mutually acceptable by all parties in conflict (and not only with a favourable outcome for one of them, as it is in the case of a court order) [Report: Amicable settlement..., 2014, p. 7; Regulating Dispute Resolution..., 2014; Roberts, Palmer, 2005; Berger, 2009; Park, 2012; Human Rights in International..., 2009; Rogers, 2014]. "Parties themselves are in charge of the process and may organize it as they wish and terminate it at any time" [Directive of 21 May 2008., Art. 13 justification]. The mediator makes sure interests of all parties are properly protected and works out a consensus acceptable by them. Mediation is not identical with the concepts of conciliation, arbitration, or negotiation. On the basis of EU law Member States courts of general jurisdiction were obliged to give a declaration of enforceability of such agreements, which content is not "contrary to their national law, including their private international law" [Directive of 21 May 2008, Art. 19 justification]. If Member State's law does not provide for enforceability of a specific 
agreement, then also there are grounds to refuse granting the enforcement clause. The power of the clause is no different from the power of agreements concluded before courts. Unfortunately, so far Polish citizens apply this efficient alternative in a marginal way (see: Table 3.).

TABLE 3.

The records of commercial cases in mediation in 2010-2020

\begin{tabular}{|c|c|c|c|c|c|c|}
\hline \multicolumn{1}{|c|}{ Description } & $\mathbf{2 0 1 0}$ & $\mathbf{2 0 1 1}$ & $\mathbf{2 0 1 2}$ & $\mathbf{2 0 1 3}$ & $\mathbf{2 0 1 4}$ \\
\hline $\begin{array}{c}\text { District } \\
\text { Courts }\end{array}$ & $\begin{array}{c}\text { number of cases in which parties } \\
\text { were directed to mediation under } \\
\text { a court order }\end{array}$ & 656 & 1053 & 1640 & 1656 & 1834 \\
\cline { 2 - 8 } & $\begin{array}{c}\text { proceedings discontinued as a result } \\
\text { of an approval of settlement } \\
\text { reached before a mediator }\end{array}$ & 142 & 182 & 299 & 340 & 296 \\
\hline \multirow{2}{*}{$\begin{array}{c}\text { Regional } \\
\text { Courts }\end{array}$} & $\begin{array}{c}\text { number of cases in which parties } \\
\text { were directed to mediation under } \\
\text { a court order }\end{array}$ & 192 & 376 & 739 & 1156 & 1262 \\
\cline { 2 - 8 } & $\begin{array}{c}\text { proceedings discontinued as a result } \\
\text { of an approval of settlement } \\
\text { reached before a mediator }\end{array}$ & 27 & 71 & 129 & 195 & 251 \\
\hline & Total & $\mathbf{1 0 1 7}$ & $\mathbf{1 6 8 2}$ & $\mathbf{2 8 0 7}$ & $\mathbf{3 3 4 7}$ & $\mathbf{3 6 4 3}$ \\
\hline
\end{tabular}

Source: own study based on: [Quantitative analysis..., 2015, p. 6].

\section{The excellent alternative and yet unpopular}

The unsatisfactory state has been further aggravated by unequal access to mediation and arbitration offered in the country, so that there are deficient areas in this regard, and sometimes even "blank spaces". The Podlaskie region is one of them. What is the reason? Is the local trading not in need of arbitration and mediation? Or rather is it about being accustomed to their absence in legal realities of the region? Probably, the fact that potential defendants do not know arbitration and mediation and the local palestra underestimates them, is also relevant. As it seems, the nature of the local society is a no less important cause of the current absence of arbitration and mediation in the Podlaskie region. It is manifested in the penchant for submitting disputes to courts, in almost instinctive submissions of appeals against judgments, complaints or requests for reopening of proceedings. These trends are beyond the common-sense approach preventing a conclusion of agreements beneficial to all parties in a dispute. It is certainly worth reversing.

Why should arbitration and extra-judicial mediation be favoured? Firstly, the methods are successfully used not only at the international and foreign level, but mainly in other regions of the country. It is worth underlining that thanks to use of alternative disputes resolution instruments the fundamental right of access to justice by companies, including reasonable duration of procedure, exposed by the Court of Justice of the European Union (CJEU) in the wide range of caselaw regarding the excessive length of judicial proceedings and the issue of remedies connected thereto (i.a. C-185/95 P Baustahlgewebe, 
dated 17 December 1998; as well as more recent cases: C-385/07 P, Der Grüne Punkt - Duales System Deutschland dated 16 July 2009; C-385/07 P, Der Grüne Punkt case dated 16 July 2009; C-50/12 P Kendrion, dated 26 November 2013; C-58/12 P the Groupe Gascogne dated 26 November 2013; C-40/12 P Gascogne Sack Deutschland dated 26 November 2013), can be transformed into effective enforcement procedures.

In addition, regarding their advantages, the following features are worth mentioning: the possibility to select arbitrators and mediators (according to their competence and achievements, with respect to the merits of a dispute), the quality of proceedings, taking into account specificities of a particular case, in general a shorter time taken to resolve a dispute. For a change - in the judiciary system parties do not have any influence on how the judge will consider their case - whether it will be a matter of routine for them or maybe their initiation in the subject. In connection to it - the quality of hearings is diverse, they tend to be carried out meticulously, even taking into account details irrelevant to a case ("just in case"), resulting in inconveniences for parties and an extended time of proceedings. And it is not the only weakness of the judiciary system.

The question arises why, despite the obvious shortcomings in courts, commercial entities, guided by business logics, after all, still prefer them? In the doctrine it is generally believed that several key issues are determined as the criteria to compare the general justice system to arbitration and mediation. Firstly, understandable and measurable for everybody proceeding costs and fees which are varied (from low to very high - depending on an institution and the amount in dispute) and not charged to the state budget. In the general judiciary system the issue is regulated in an entirely different manner. In the budget for 2015 it is provided that for the activity of 339 courts (11 appellate courts, 45 regional courts, 283 district courts, 1 Institution of Budgetary Economy), the state will issue 6692742 thousand zlotys, and the revenues will amount to 2129163 thousand zlotys. The expenditure includes: compulsory social security (including emoluments of retired judges and family salaries), judiciary (units of courts and other activities), education (other forms of education specified separately). For example, the Court of Appeal in Bialystok will have the revenue of 121076 thousand zlotys, and the spending is planned at the amount of 409334 thousand zlotys [bip.ms.gov.pl/pl/dzialalnosc/ budzet/download,2875,0.html (accessed: 13.04.2015)].

It should also be taken into consideration that during proceedings (generally shorter than court ones) a dispute settlement body (as already mentioned, a judge is not always an expert in the scope of a case, whereas an arbitrator / arbitrators or a mediator are chosen by parties according to their substantive competence), rules of evidence (more formalized in courts), confidentiality of proceedings (in courts, as a rule, open to the public, and in arbitration and mediation strictly confidential), level of communication intensity between parties during a case (in courts essentially there is none, in arbitration it is present and in mediation it is significant), problems with jurisdiction (in the judiciary system they occur more frequently), or results of settlement for each party (in court and arbitration - success on one party and loss for the other, in mediation a consensus is reached by both parties). The synthetic comparison between the general jurisdiction and arbitration and mediation is summarized in the table (see Table 4.). 
TABLE 4.

The comparison of the effectiveness of the general justice, mediation and arbitration

\begin{tabular}{|l|c|c|c|}
\hline \multicolumn{1}{|c|}{ Criteria } & General justice & Arbitration & Mediation \\
\hline Costs of proceedings & high & varied (from low to very & very low \\
Duration of proceedings & very long & varied & very short \\
Who decides? & judge & arbitrator / arbitrators & parties \\
Rules on presenting & very formalized & formalized in varying & none \\
evidence & & degrees & full \\
Confidentiality & none & full & intense \\
Communication between & none & little & none \\
parties & present & varied & success for both \\
Problems with jurisdiction & success / loss & success / loss & parties \\
Result for parties & & &
\end{tabular}

Source: own study based on: [Pieckowski, 2012, p. 4].

\section{Arbitration and mediation in the Podlaskie region}

So far in Bialystok intense and effective efforts to launch an alternative system of justice in the field of arbitration and mediation have been made [more information about the initiative to create the Eastern Court of Arbitration: http://bialystok.tvp.pl/19083567/ w-bialymstoku-powstanie-wschodni-sad-arbitrazowy (accessed: 04.20.2015); http://www.podlaskie.strefabiznesu.pl/artykul/cel-wschodni-sad-arbitrazowy-w-bia lymstoku (accessed: 20.04.2015)]. Regarding them, the concepts of the Chamber of Industry and Commerce in Bialystok implementing the project "Centra Arbitrażu i Mediacji - projekt pilotażowy" (Arbitration and Mediation Centres - a trial project) and the Faculty of Law at University of Bialystok (originally the launch of arbitration was envisaged there) came together, which resulted in the actual project (the Faculty of Law provided personnel and substantial facilities, and the Chamber - organizational tasks and basic financial means), in which the Author is directly involved. Until now mediation as a part of the Podlaskie Arbitration and Mediation Center at the Chamber of Industry and Commerce in Bialystok was launched [http://www.iph.bialystok.pl/index.php?option $=$ com_content\&view $=$ article\&id=130\&Itemid $=212 \& l a n g=p l($ accessed: 17.04 .2015$)]$, whereas the works on starting arbitration are ongoing. The Author suggested the name "Eastern Court of Arbitration", which was warmly welcomed by stakeholders, as well as by the socio-economic environment. The statutory and regulations of the institution [http://www.iph.bialystok.pl/wp-content/uploads/2015/10/Regulamin_Wschodniego _S\%C4\%85du_Arbitra\%C5\%BCowego_20150624.pdf (accessed: 17.06.2015)] were prepared and the Court started its operation [http://www.iph.bialystok.pl/wscho dni-sad-arbitrazowy (accessed: 17.06.2015)]. Will such a venture be profitable? 
In commercial courts of the Podlaskie region, in order to resolve a dispute, parties have to wait. According to local practitioners (interview with Judge Tomasz Kaluzny [Więcko, 2015, pp. 9-10]; interview with Witold Karczewski and Maciej Bobrowicz, $\mathrm{PhD}$ [http://www.radio.bialystok.pl/gosc/index/id/119208 (accessed: 20.04.2015)]), arbitration allows for professional handling of cases. The range of specialists among judges, although it is relatively large, is not developed adequately to the complexity and diversity of legal transactions. Thus, either courts alone dodge unpopular categories of cases (e.g. questioning their jurisdiction), or defendants do not bring these issues to courts which do not specialize in the field. This is an opportunity for ADR, especially for arbitration. For instance, the author initiated governing civil disputes of local government units and disputes arising from their international (mostly cross-border) activities by the Eastern Court of Arbitration [cf. Perkowski, 2014, pp. 266-270; Perkowski, 2013, pp. 292-310; Perkowski, 2012, pp. 105-112].

Moreover, taking advantage of the cross-border location and excellent contacts of the Chamber of Industry and Commerce (based on its business successes) and the University of Bialystok (especially the Border University Network guaranteeing access to potential arbitrators and mediators from the East) in the East - the Eastern Court of Arbitration can specialize in settling commercial disputes related to cooperation in this business direction. These original competence assets seem important factors in the success of the newly-formed arbitration unit. Arbitration in the Podlaskie region is not only a novelty, but also an opportunity. Many authorities from entrepreneurs, practitioners to researchers are involved in its promotion, which makes it credible in its starting period. In addition, Bialystok is not "lackadaisical" in the market terms and legal expertise here is not expensive. This factor may be attractive from the perspective of entrepreneurs from other regions of the country.

\section{Summary}

The Eastern Court of Arbitration in Bialystok passed the planning stage successfully and currently it is in the phase of sui generis "embryonic development.". It initiated its activities in June 2015 and its operation is under observation. The assessment criteria are: increase in cases heard by the Eastern Court of Arbitration (in total), an average time for processing, a selection of the Eastern Court of Arbitration arbitrators, the quality and satisfaction of defendants (which should not be understood directly, but from the view of effectiveness of potential appeals from arbitrators' decisions). The procedural practice of the Eastern Court of Arbitration may also pose a problem. In the beginning submitting and hearing cases can be problematic, but over time difficulties will be overcome and it will reach full professionalism.

Considered a role model of order and organizational efficiency Germans say: "Übung macht den Meister" (Practice makes perfect). May the Podlaskie Arbitration and Mediation Center and the Eastern Court of Arbitration attain the best sense of efficiency and cost-effectiveness, and their clients and defendants - reasonable results. 


\section{References}

Act of 17 November 1964 - the Code of Civil Procedure, OJ, 1964, No. 43, item. 296, as amended.

Arbitration, dispute resolution and mediation catalogue of the Cambridge University Press, http://www.cambridge.org/us/academic/subjects/law/arbitration-disputeresolution-and-

mediation $/$ ?layout $=$ listing\&pageSize $=50 \&$ Series $=\&$ sortOrder $=$ answerMpubDat e_unified_N[desc] (accessed: 20.04.2015).

Arbitraż, w prawie miedzynarodonym, 2014, C. Mik (ed.), Wydawnictwo C. H. Beck, Warsaw. Bełdowski J., Metelska-Szaniawska K., 2007, Law \& Economics - geneza i charakterystyka ekonomicznej analisy prawa, „Bank i Kredyt”, October.

Berger K. P., 2009, Private Dispute Resolution in International Business-Negotiation, Mediation, Arbitration, vol II: Handbook, Kluwer Law International, AH Alphen aan den Rijn.

Blake S., Browne J., Sime S., 2014, A Practical Approach to Alternative Dispute Resolution, Oxford University Press, Oxford.

C-185/95 P Baustahlgewebe, dated 17 December 1998.

C-385/07 P, Der Grüne Punkt - Duales System Deutschland dated 16 July 2009.

C-385/07 P, Der Grüne Punkt case dated 16 July 2009.

C-40/12 P Gascogne Sack Deutschland dated 26 November 2013.

C-50/12 P Kendrion, dated 26 November 2013.

C-58/12 P the Groupe Gascogne dated 26 November 2013.

Case-law of the Court of Justice of the European Union.

Complaint against Excessive Length of Proceedings against the Records of Cases in General Courts and Duration of Court Proceedings in 2010-2014, 2015, Ministry of Justice, Warsaw.

Directive of the European Parliament and of the Council 2013/11 / EU of 21 May 2013 on Alternative Dispute Resolution for Consumer Disputes and Amending Regulation (EC) No 2006/2004 and Directive 2009/22 / EC (Directive on ADR for consumer disputes), OJ L 165/63 of 06.18.2013.

Directive of the European Parliament and the Council 2008/52 / EC of 21 May 2008 on Certain Aspects of Mediation in Civil and Commercial Matters, OJ L 136/3 of 24.05.2008. http://bialystok.tvp.pl/19083567/w-bialymstoku-powstanie-wschodni-sadarbitrazowy (accessed: 20.04.2015).

http://bip.ms.gov.pl/pl/prawa-czlowieka/europejski-trybunal-prawczlowieka/podstawowe-informacje-dotyczace-skladania-skargi-doeuropejskiego-trybunalu-praw-czlowieka/ (accessed: 18.04.2015).

http://www.cambridge.org/us/academic/subjects/law/arbitration-disputeresolution-and-

mediation $/$ ?layout $=$ listing $\&$ pageSize $=50 \&$ Series $=\&$ sortOrder $=$ answerMpubDat e_unified_N[desc] (accessed: 20.04.2015).

http:/ $/$ www.iph.bialystok.pl/index.php?option $=$ com_content\&view $=$ article\&id $=1$ 30\&Itemid $=212 \&$ lang $=\mathrm{pl}$ (accessed: 17.04.2015). 
http://www.iph.bialystok.pl/wp-con-

tent/uploads/2015/10/Regulamin_Wschodniego_S\%C4\%85du_Arbitra\%C5\% BCowego_20150624.pdf (accessed: 17.06.2015).

http://www.lex.pl/czytaj/-/artykul/ets-bedzie-mogl-byc-pozwany-za-przewleklyproces (accessed: 18.04.2015).

http://www.podlaskie.strefabiznesu.pl/artykul/cel-wschodni-sad-arbitrazowy-w-

bialymstoku (accessed: 20.04.2015).

http://www.radio.bialystok.pl/gosc/index/id/119208 (accessed: 20.04.2015).

Human Rights in International Investment Law and Arbitration, 2009, P.M. Dupuy, E.U.

Information on the Activities of the Ombudsman in 2013 and on Observance of Human and Civil Rights and Freedoms 2014, S. Trociuk (ed.), Warsaw

Keller H., Forowicz M., Engi L., 2010, Friendly Settlements before the European Court of Human Rights. Theory and Practice, Oxford University Press, Oxford.

Litigating International Law Disputes. Weighing the Options, 2014, N. Klein (ed.), Cambridge University Press, Cambridge.

Mackie K. et al., 2007, The ADR Practice Guide: Commercial Dispute Resolution, Tottel, Haywards Heath.

Maraszek M., 2011, Model przestepcy racjonalnego i efektywna polityka karna - okiem praktyka, „Prokurator”, No 3(47).

Mediation: Principles and Regulation in Comparative Perspective, 2013, K. J. Hopt, F. Steffek (eds.), Oxford University Press, Oxford.

Morek R., Rozdeiczer L., 2013, Mediation in Poland: Time for a Quiet Revolution?, [in:] Mediation: Principles and Regulation in Comparative Perspective, K. J. Hopt, F. Steffek (eds.), Oxford University Press, Oxford.

Park W. W., 2012, Arbitration of International Business Disputes. Studies in Law and Practice, Oxford University Press, Oxford.

Partidge M., 2009, Alternative Dispute Resolution: An Essential Competency for Lanyers, Oxford University Press, Oxford.

Paulsson J., 2013, The Idea of Arbitration, Oxford University Press, Oxford.

Perkowski M., 2013, Miedzynarodowa wspótpraca wojewódžtw w prawie i praktyce, Temida 2, Bialystok.

Perkowski M., 2014, Arbitraż a międzynarodowa wspótpraca regionów. Uwagi de lege lata i de lege ferenda, [in:] Arbitraż w prawie miedzynarodowym, C. Mik (ed.), Warszawa.

Pieckowski S., 2012, Mediacje w sprawach gospodarcaych. Stan prawny na 1 grudnia 2012 r., Oficyna Wydawnicza Ministerstwa Sprawiedliwości, Warsaw.

Quantitative Analysis of Records of Commercial Cases in 2010-2014, 2015, Ministry of Justice, Warsaw.

Regulating Dispute Resolution. ADR and Access to Justice at the Crossroads, 2014, F. Steffek, H. Unberath (eds.), Oxford University Press, Oxford.

Report: Amicable Settlement of Consumer Disputes in 2014, the Office of Competition and Consumer Protection, Warsaw.

Roberts S., Palmer M., 2005, Dispute Processes. ADR and the Primary Forms of DecisionMaking, Cambridge University Press, Cambridge.

Rogers C., 2014, Ethics in International Arbitration, Oxford University Press, Oxford. 
Steffek F., 2013, Mediation und Justiz, [in:] Das neue Mediationsgesetz-Rechtliche Rabmenbedingungen de Mediation, C. Fischer, H. Unberath (eds.), CH Beck, Munich.

Stelmach J., Brożek B., Załuski W., 2007, Driesiéć wykładów o ekonomii prawa, Oficyna Wolters Kluwer Businnes, Warsaw.

Tokarczyk R., 2007, Jednostronność ekonomicznej analisy prawa, „Ruch Prawniczy, Ekonomiczny i Socjologiczny", vol. 4.

www.pssp.org.pl (accessed: 16.04.2015). 